\title{
THE SOCIAL VALUE IN NURSING STUDENTS' DISCOURSE: A PHENOMENOLOGICAL ENCOUNTER WITH MAX SCHELER
}

\author{
Gilberto de Lima Guimarães', Tania Couto Machado Chianca², Vania Regina Goveia ${ }^{3}$, Kleyde Ventura de Souza ${ }^{4}$ \\ Isabel Yovana Quispe Mendoza ${ }^{5}$, Ligia de Oliveira Viana ${ }^{6}$
}

\footnotetext{
${ }^{1}$ Ph.D. in Nursing. Professor, Universidade Federal de Minas Gerais (UFMG). Belo Horizonte, Minas Gerais, Brazil. E-mail: drgilberto. guimaraes@hotmail.com

2 Ph.D. in Nursing. Professor, UFMG. Belo Horizonte, Minas Gerais, Brazil. E-mail: taniachianca@gmail.com

${ }^{3}$ Ph.D. in Nursing. Professor, UFMG. Belo Horizonte, Minas Gerais, Brazil. E-mail: vaniagoveia@ufmg.br

${ }^{4}$ Ph.D. in Nursing. Professor, UFMG. Belo Horizonte, Minas Gerais, Brazil. E-mail: kleydeventura@gmail.com

${ }^{5}$ Ph.D. in Nursing. Professor, UFMG. Belo Horizonte, Minas Gerais, Brazil. E-mail: isabelyovana@ufmg.br

${ }^{6}$ Ph.D. in Nursing. Professor, Universidade Federal do Rio de Janeiro. Rio de Janeiro, Rio de Janeiro, Brazil. E-mail: ligiaviana@uol. com.br
}

\begin{abstract}
The study aimed to identify and understand, in the student's discourse, the social value and discuss it in the light of some of Max Scheler's assumptions. The senior students in Nursing take an existential place in the world, giving it meaning and sense through their opinion. The research is qualitative with a phenomenological approach. The subjects were 10 senior students from the Nursing course in Belo Horizonte, Minas Gerais, Brazil. Data were collected from August to September, 2014, through interviews. Dilthey's hermeneutics was used to unveil the meaning of the statements. The social value emerged in the discourse, expressing solidarity based on sympathy. The social value was recognized as a constituent of the axiological field that founds the profession and is essential for nursing care. It is acknowledged that the "logic of reason" and the "logic of the heart" are complementary and combine the art and science of nursing. DESCRIPTORS: Nursing. Culture. Social values. Philosophy. Students, nursing.
\end{abstract}

\section{O VALOR SOCIAL NO DISCURSO DO DISCENTE DE ENFERMAGEM: UM ENCONTRO FENOMENOLÓGICO COM MAX SCHELER}

RESUMO: O objetivo deste estudo foi identificar e compreender, no discurso do discente, o valor social e discuti-lo à luz de alguns pressupostos de Max Scheler. O discente concluinte do Curso de enfermagem ocupa lugar existencial no mundo, dando-lhe significado e sentido por meio de sua valoração. Pesquisa qualitativa com enfoque fenomenológico, da qual participaram dez discentes concluintes do Curso de Enfermagem, em Belo Horizonte, Minas Gerais, Brasil. Os dados foram coletados de agosto a setembro de 2014, por meio de entrevista. Usou-se a hermenêutica diltheyniana para desvelar o sentido das falas. $\mathrm{O}$ valor social emergiu nos discursos, expresso pela solidariedade a partir da simpatia. O valor social foi reconhecido como constituinte do campo axiológico que fundamenta a profissão e essencial para o cuidado de enfermagem. Admite-se que lógicas complementares que conjugam a ciência e a arte da enfermagem são a "lógica da razão" e a "lógica do coração".

DESCRITORES: Enfermagem. Cultura. Valores sociais. Filosofia. Estudantes de enfermagem.

\section{EL VALOR SOCIAL EN EL DISCURSO DEL ESTUDIANTE DE ENFERMERÍA: UN ENCUENTRO FENOMENOLÓGICO CON MAX SCHELER}

RESUMEN: El objetivo de este estudio fue identificar y discutir el valor social bajo algunos presupuestos de Max Scheler en el discurso del estudiante de enfermería. Se asume que el estudiante de la carrera de Enfermería ocupa un lugar existencial en el mundo que le otorga significado y sentido a través de su opinión. Investigación cualitativa con enfoque fenomenológico. Los sujetos fueron 10 estudiantes de la carrera de Enfermería en Belo Horizonte, Minas Gerais, Brasil. Los datos fueron colectados entre agosto y septiembre de 2014 mediante entrevista fenomenológica. Para el análisis se utilizó a hermenéutica Diltheyniana que permitió revelar el sentido en las declaraciones. El valor social emergió en los discursos, expreso por la solidaridad apartir de la simpatia. Este valor fue reconocido como componente de campo axiológico de la profesión y la esencia para el cuidado de enfermería. Se admite que las logicas complementares que conjugan la ciencia y el arte de enfermería son la "lógica de la razón" y "lógica del corazón".

DESCRIPTORES: Enfermería. Cultura. Valores sociales. Filosofía. Estudiantes de enfermería. 


\section{INTRODUCTION}

The Brazilian society is currently absorbed in a crisis, and it seems that the relation between capital and ethics has appointed the existence of a dilemma that surpasses the material dimension. After all, what makes a member of society take improper possession of public resources, ignoring the present and future implications of his actions? What makes a magistrate justify the ownership of other people's goods in favor of himself? What makes some health professionals accept "gratifications" to recommend the use of a product or medical-hospital equipment? These and other issues demonstrate that selfishness penetrates the different forms of social relationship, producing an axiological inversion.

In that sense, the current nature of Scheler's thinking is noteworthy, as what underlines the proposed questions is the expression of bourgeois ethos. Its appearance in social praxis feeds all sorts of distortions, considering that its nature is to prioritize the ownership of goods to the detriment of individuals' growth and development, leading them to selfishness, greed, insensitivity and the denial of the other as a person. Thus, "cunningness', the attitude of "taking advantage", "excessive personal interest" become ways to achieve the modus operandi in social relationships, promoted by the bourgeois ethos. Thus, the other person is seen as an object, and having becomes the pivotal point in life, to the detriment of being. ${ }^{1}$

In that context, senior nursing students with needs, not only in the biological sense, but mainly in the sense of spiritual accomplishments, yearn to be worth more, not only in the biological sense, but mainly in the sense of spiritual accomplishment, anxious for greater worth, not only in the field of their materiality, but also in the development and growth in the Nurse-being. As existential beings, absorbed in a given culture, nourishing on the spirit of their time, they are capable of giving it meaning. Therefore, it is through the values that the students, in the course of their education, incorporate this meaning and execute it in their action. ${ }^{1-3}$

In principle, however, the fact of being a senior does not guarantee that, in the future, its professional action will root in the Nurse-being. No matter how paradoxical it may be, it is perfectly possible to get the degree without the student's development and ascension to the Nurse-being as, for that purpose, in academic education, the science and art of nursing should be linked. ${ }^{4}$

We believe that the crisis in the current society is exercising a strong appeal on the students, moving them in an opposite sense to what is indicated by the axiological field of the profession. The influence of the bourgeois ethos can make the students search happiness as a form of social acknowledgement and make them insensitive to the fundamental values of nursing.

Next, the elements of nursing science grant it the objectivity, that is, the logical-rational and empirical disciplinary knowledge, such as biology, anatomy, physiology, pathology, among others. This knowledge founds the art, starting with the disciplines that relate to the nursing techniques, but comprise the non-disciplinary knowledge, such as love, solidarity, ethical commitment, experienced in the continuing exercise of nursing learning. The growth and development of these elements by the students, in the course of their academic education, move them towards the Nurse-being. ${ }^{5}$

Therefore, the nurse-teacher, in the act of educating, should move the students towards reflecting on the apprehension of these constituent elements, considering that underlying the science and the art of nursing are the values that guide their professional action, expressed in nursing care. ${ }^{6}$

Considering the implications of the term nursing care, its concept needs to be established to solve any doubts or controversies. Care is considered as diligence, solicitude towards people and the community. It is a mode of being with the other as a person, concerning the special issues of life, ranging from birth till death, covering the different situations of the health and disease process, based on the science and art of nursing. ${ }^{3-5}$

We depart from the premise that nursing, as social practice, possesses a set of values that grant it meaning, that is, they say what it is and grounds its pragmatics based on nursing care. In that sense, the useful value, the truth value, the social value and the ethical value comprise the axiological field listed by Florence Nightingale, constituting the professional value scale. The experience of these values molds them as a person and approaches them to the Nurse-being. ${ }^{6-7}$

Thus, it is in the field of social practice, in their coexistence with the other, being peers, teachers and, mainly, in care for the patients under their care or the community, that the senior students reveals them how they are moving towards the signifying of the Nurse-being. ${ }^{3}$

Thus, reflecting on the valuation the students undertake in their academic education becomes vital to be able to understand the direction they give to the signifying of the profession, and allows us to 
judge the role nurse-teachers play in this process. This valuation capacity is expressed in the value scale the senior students elaborate for themselves. ${ }^{8}$

The justification to develop the study rested on the assertion that the senior students, in the course of their academic background, mediated by the nurseteacher's act of educating, approached knowledge that composed the science and art of nursing and, consequently, the axiological field of the profession, submitting it to criticism and reflection, confronting it with the axiological field of the bourgeois ethos. In this encounter, this knowledge could be recognized, discussed and re-ranked. Thus, we start to question which nursing values the nursing students were able to learn in their academic education. ${ }^{1}$

We depart from Scheler's perspective to seek the evaluative understanding, as we share the view that the values are apprehended by feeling instead of reason.

In his approach to the gnosiological problem of value, the theorist departed from an effort to show the overcoming of the shortages of the formalist view of Kant's heritage as well as of the exclusively materialistic view of the ethics of goods and ends. He perceived that a pure rational formalism of duty was unworkable without an intuitive completion, a purely formal intention, without matter. Thus, the foundation for ethics cannot be simply the duty as a formal a priori category of reason, which would lead to an imperative and arbitrary ethics. Pursuing these intuitions, he developed an anthropology centered on the person as a spiritual being, as an organicspiritual unit open to the world, the person as the center of a wide range of intuitive, intentional and conscious, not only rational spiritual acts. ${ }^{1}$

In view of these considerations, the objective in this work was to identify and understand, in the senior students' discourse, the social value and discuss it in the light of some premises of Max Scheler.

\section{METHOD}

Qualitative research with phenomenological focus. This approach is intended to understand the daily life world, in the attempt to clarify the meaning of the descriptive reports of social life, allowing the researchers to understand the experience focused on the meanings of perceiving. Their research object is the phenomenon that shows itself to them and by itself. ${ }^{9}$

The study context was a higher nursing education institution located in the city of Belo Hori- zonte, Minas Gerais, Brazil. The research complied with the parameters of National Health Council (CNS) Resolution 466/12 and was forwarded to the Ethical Research Committee of Universidade Federal de Minas Gerais, registered under CAAE 26467213.2.0000.5149. The data were collected after the subjects had been informed on the ethical aspects of the research and had signed the Free and Informed Consent Form.

The technique used to collect the data was the phenomenological interview, recorded using electronic media, based on the following guiding question: how do you assess the Nurse-being? The phenomenological interview comes with peculiarities that had to be taken into account for the sake of its strict use. Hence, the need for perception was demanded from the researchers, in the following sense: seeing and observing, free from prejudices, in an empathetic relationship, characterized by a state of approximation, valuing and respecting each person; interpreting the interviewee's language and meaning comprehensively, based on active listening, staying receptive and avoiding judgments that could interfere in the interviewees' narrative. The interviewers were teachers from the research institution. The criterion for inclusion in the sample was the student's belonging, being regularly enrolled in the final semester of the undergraduate nursing course. $^{9}$

The participants were defined by means of a convenience sample. The researchers contacted 45 students in advance by e-mail, through an invitation letter. Eighteen of them agreed to participate and a face-to-face meeting was scheduled. On that occasion, the content of the research was presented and, with all participants' agreement, a new appointment was made for the interview, which was held in a private room at the research institution, with an average duration of 40 minutes. The subjects were ten senior students. This number was determined after the data saturation and after the phenomenon had revealed itself to the researchers' awareness. They were identified by means of an alphanumerical system in the text, using the letter E followed by Arabic numerals between 1 and 10 . The interviews were held between August $10^{\text {th }}$ and September 30 2014.

Using Dilthey's hermeneutics, the meaning of the statements was unveiled with a view to understanding the statements. It is considered to be the first truly philosophical hermeneutics, inspired on Schleiermacher's philological hermeneutics, which ceased to be a mere interpretative technique 
and turned into a comprehensive method. Wilhelm Dilthey developed his thinking in the sense of an intentional search to understand the expressions of human experiences based on the written text. ${ }^{10}$

The notion of understanding is the core in the elaboration of hermeneutical thinking. This epistemological attitude is not merely the objectification towards the object given, as understanding is a movement of the subject's belonging to the being of what is understood. In that process, it is fundamental for the interpreter to pre-understand, that is, to have information on the historical-fundamental plot underlying the subjects' context as, without this background knowledge, the game of circularity cannot initiate. Through this game, the interpreter takes on the commitment to proceed with the exhaustive reading and rereading of the text, until the elements behind its meaning are unveiled to his awareness. ${ }^{10}$

Thus, the interpreter should seek what is alluded or referred to or associated, in order to reach what ends up resulting in what was aimed for. As a result, the written text serves as a whole based on which the thinking should be understood as something particular and vice-versa. Hence, the analysis of the text cannot be done at one go because, at every new reading, a bit more is understood, as the knowledge needed for the sake of a better understanding is gradually incorporated. ${ }^{10}$

It is also highlighted that Dilthey's hermeneutics does not present a clear technique to analyze the collected data. Therefore, some of his premises were adapted and used as a guide. For this study, the following analysis steps were constructed: first, the deponents' statements were fully transcribed and forwarded for validation by the subjects. After returning the transcriptions, they were read to get familiar with the whole and, then, they were reread. Next, starting the game of circularity, attentive and detailed reading of the text took place countless times, until the definitive nature of the discourse was revealed to the awareness. Then, the ideas that emerged in the interpreter's awareness were written down, promoting their respective clustering to originate the units of meaning. ${ }^{10-11}$

The units of meaning express a meaning by themselves and in relation to the contexto. They can be a word, a frase or paragraph. What matters is that there exists a set of propositions that express a certain theme, based on which the values the students attribute to nursing are obtained. Finally, the contente was discussed in the light of some premises from Scheler's value scale and the scientific literature. ${ }^{11}$

\section{RESULTS AND DISCUSSION}

The mean age of the interviewees was 22 years. Three of them were male and seven female. This profile ratified the influence of the female gender on the career and also showed the trend to include young individuals in the profession, clearly strengthened by the expansion in Brazilian higher education in recent decades. ${ }^{12-13}$

The social value was manifested in the discourse and by the senior students, understood as a meaning of a to-be, as this value favored human life as part of the group, establishing solidarity in praxis. ${ }^{14}$

According to the theorist, in praxis, this initiation can only happen because solidarity is not just a human activity, but an essential characteristic of people, together with individuality and spirituality. Although people are absolute and unique, by themselves and in their world, since their origin, they discover themselves as social beings, necessary and open to a wider universe. This fact originates in the understanding of their finiteness and limitation, so that they need to open up to the others and establish relations of complementation and cooperation with them. That is the sense Scheler applies. ${ }^{1}$

Hence, distant from seeming like a loner living on an island, without doors or windows, people feel the need to seek others, open up to the external world, receive and relive extraneous experiences, with a view a to enrichment and complete accomplishment. It is exactly in this giving and receiving that they feel like a "being-with-the-others" and co-responsible for everything that happens in the community. ${ }^{7}$

Therefore, for Scheler, solidarity is the desired growth and development point of the human being in the social value, as it underlies the development of the ideal society. From that perspective, collective life becomes the unit of singular, autonomous, spiritual and individual people living in equality, in which people are responsible for themselves and co-accountable for the others. ${ }^{14}$

The attitude of solidarity was mainly experienced based on the establishment of Scheler's I-You relation by the senior student. The deponents illustrated this assertion by affirming that: [...] In technical and practical aspects, I am able to attend to their [nurses'] requests. In addition, during the $10^{\text {th }}$-term training, at the pediatric ward, I am able to contribute to the treatment [...] being at the child's side, expressing support for the family. Witnessing the child getting better is gratifying (E1). [...] I consider that, as a profession, nursing can 
produce more solidary care, being at the side of the patient and family, concerning and attempting to help the child to go through the moment of the hospitalization (E10).

In the deponents' statements, it was verified that the understanding about the meaning of Beinga-Nurse was not restricted to the aspects involved in the logical-rational and empirical science. They considered that their action should go wide, beyond technical-scientific acting. ${ }^{3}$

According to them, nursing care extended to the emotional support to the family, and they understood that "being at the side" of the patients was not a mere duty to comply with a technical requisite, but a way to acknowledge their humanity and need, expressing the necessary emotional support to the participants in the care process, especially the patients and their relatives. ${ }^{6-8}$

This fact is healthy, as humans feel more vulnerable when their health condition is ruptured. It does not matter whether this happens to them or close people. The suffering arouses the idea of finiteness and frailty, and feelings of fear, anguish and solitude are common, that is, the being feels human, and not a machine. ${ }^{7}$

Hence, moved by the social value, manifested in collective life through solidarity, the senior student got closer to the patient and relative. This attitude was only possible due to the fact that solidarity is intrinsic in the human condition, as the asymmetries and inequalities mobilize this dimension in people. ${ }^{15}$

At the same time, it was clear to the senior students that their attitude was important to favor the wellbeing of the individuals under their care. Their attitude of being at the side of the patients and their relatives was manifested as part of the essence of nursing. Moving in this way, they started to acknowledge the patients not as objects, but as people and, thus, as possessing not only physical or biological needs. By proceeding as such, they moved away from the perspective imposed by mass social clustering and started to value the individual as a being in a state of lacking social value. ${ }^{1}$

Solidarity is an intrinsic element of professional nursing practice, as the characteristics of its actions originate not only in knowledge of scientific and technical subjects, but also in personal knowledge deriving from the ethics and esthetics of care. This link is presented to the students throughout their education. ${ }^{5}$

Thus, in a peculiar and creative manner, nursing starts to cover aspects of the science and the art, allowing the nursing care to be conceived as the practice and knowledge of the profession, expressed in the praxis that rests on the acknowledgement of each patient's personality. ${ }^{3}$

This perception is possible, in view of the important constitutive facet inherent in solidarity, that is: sympathy. Through this, people can move beyond their individuality and participate in the others' feelings and, guided by love, identify themselves and turn to other human beings for the sake of emotional accomplishment. Sympathy takes two forms: feeling with and sympathizing with the other. "Sympathizing with" makes them aware of the particular case of the other, as well as a reality equal to our own I. Considering the others as equals is the base of the movement of spontaneous love for human beings. "Feeling with the other" is not enough, as one can perfectly feel with the actor in a theatre play, feel the same joy and sadness, without this act entailing any further meaning or activity to overcome the other person's need. ${ }^{12}$

Thus, what sympathy is concerned, the theorist affirms that human beings live more in the others than in themselves, more in the community than in their individuality. It is through emotiveness that he constructs his theory about the perceptual apprehension of the other, highlighting sympathy and love. Hence, the theorist breaks with the Cartesian tradition and with the related prejudices. His basic assertion is that, in the apprehension of the other, it is not his body that is perceived, but the whole, which appears loaded with subjectivity and shows itself as an expression. ${ }^{1}$

Therefore, due to the transcendence that characterizes them, sympathy and love permit understanding the patients to different extents and participating in the acts of which they are the center. Nevertheless, Scheler does not consider the empirical experience of this contact any more relevant. At least the physical presence of the other does not reveal further significance, except to confirm an intuitive availability. In fact, that presence is merely circumstantial. What is important is the a priori condition of the other's presence in our experience. This is not an innate thesis, but an intuition that, on the one hand, seems to be insinuated by a relevant experience: the void, which is completed through the other's empirical presence. ${ }^{1}$

In view of this consideration, it is correct to affirm that the senior students acknowledged sympathy as a form of standing before the patients, perceiving them as equals, recognizing their singularity, valuing their humanity; and identified them 
as having axiological needs. Thus, they were able to move and establish, in social praxis, the sympathetic attitude (act of being available in the attempt to "sympathize with"). ${ }^{12}$

Similarly, it cannot be ignored that humanization is ongoing and, thus, in case of distancing from the sympathetic attitude, they will develop a position centered on indifference towards the patients, perceiving them as objects..$^{6-8}$

Thus, when the senior students revealed that "being at the side" of the patient was part of their care, they valued this sympathetic attitude as an element of solidarity. ${ }^{1}$ The deponents illustrated this consideration by considering that: [...] in fact, another point I find important is attention. The interest and attention the nurse should pay to care for the patient. Aiming to help him to overcome the moment and discover the best incentive to allow him to surpass the deprival of health (E2). [...] I believe that the nursing professional needs a caring attitude, a pro-active attitude towards big issues. He needs to be in tune with all modifications that emerge in our midst (E6). [...] nursing is vocation. It is dedication. It is being at the side of the patient and his family. I consider that there is no health without nursing (E9).

Therefore, the sympathetic attitude is a fundamental condition to exercise nursing care as, through this attitude, the senior students broke with the countervalues proposed by the contemporary society, mainly characterized by an orientation to the I-You relation, marked by the fragmentation of the being, by the reification and trivialization of the other, by the exacerbated individualism with strong trends towards dehumanization. ${ }^{5}$

To overcome this trend towards dehumanization, a new meaning of engagement in collective life needs to be assumed, which involves the resistance against the cruelty of the world, of life and human barbarity, and consequently the practice of solidarity as the establishment of social value in praxis. ${ }^{1}$

The senior students understood the importance of establishing the social value for the pragmatics of nursing care, as they were willing to break the limits the biological knowledge imposes on the career, acknowledging the need to rediscover the care praxis that values the human. Therefore, solidarity is an outstanding target because, thus, the revaluation of the patients is discovered, considering them as beings who accomplish themselves in the world with the others, a condition granted by nursing care. ${ }^{7,16}$

Thus, nursing care is an attitude of consideration, knowledge, love, solidarity and fundamental concern. It is a moral obligation of the senior nursing students, and it is through care that they, in the exercise of their responsibilities, will offer the patients support, safety, sympathy and compassion. ${ }^{17}$

Being solidary includes perceiving the patients' vulnerability, their need for care and the availability to be at their side in a comprehensive and responsible manner, that is, based on sympathy. Thus, solidarity is perceived as an exercise of citizenship, as it is intended to construct subjects instead of objects of care. Hence, it cannot be mixed up with paternalism or charity. Its responsibility is to return the human dignity that was lost, instead of subduing or perpetuating the relation between the oppressor and the oppressed. In addition, the term solidarity indicates support and is linked to the moral sense of an action with liberating goals. It seems beyond doubt that nursing, by nature, is characterized as a solidary activity. ${ }^{5}$

The deponents' considerations illustrate this assertion, affirming that: [...] to be a nurse, the professional should assume the posture of not being afraid to approach the patient, of being able to listen to him, attending to the other's needs. The nurse was very cold in this sense. He was accustomed to the "roles" and forgot about the human care. It seems to me he goes back to the fundamentals of what his being should possess (E3). [...] scientific knowledge is necessary but, in practice, other knowledge is necessary [...] the nurse needs to be capable of dealing with the patient, delivering care in its integral aspects. He needs to know physiology, pharmacology, techniques and human relations (E4). [...] we all depend on contact with the other. We depended on the past when we were children, we can become highly dependent at any time and we will become fatally dependent in the advanced phase of our lives (E7).

Based on this experience in care practice, the senior students were confronted with two realities. The first considered the nursing professionals' practice, in which they considered the nurse as technically capable, but circumscribed to the management and technical actions of care. The students acknowledged the importance of know-how for the care pragmatics, but dared to affirm that this emphasis cannot diminish the nurses' capacity to be solidary, that is, to be at the side of the patient under their professional care in an attentive and sensitive manner. ${ }^{5-8}$

Next, moved by the reflection on Beinga-nurse, originating in the provocations of his academic education process, they rediscovered the essence of nursing. They understood that, together with technical competency, human competency was necessary for professional care. Their perception 
made them acknowledge that know-how should be linked with the art of nursing. One cannot grow and develop as a Nurse-being without the people who intend to become a nursing professional experiencing this constitutive dimension. This fact is significant, as it will trigger the process for the transformation of the patient and nurse relation. ${ }^{6-7,17}$

Thus, the senior students presented that the "logic of reason" and the "logic of the heart" are complementary and not antagonistic. They ratified Scheler's position, as the theorist rejects the distinction between reason and sensitivity, according to which only the rational could define the mastery of the understandable essences, that is, the a priori mastery. It will raise the emotional to the same level as the rational, admitting a "logic of the heart" and a "logic of reason". ${ }^{1}$

Therefore, the 'logic of the heart' seems to be a dimension neither the physical-biological sciences nor phenomenology had clarified and that, nevertheless, is open to the phenomenological research approach. According to the theorist, the "logic of the heart" needs to be understood, as it is the center of affective life and houses the values. Thus, the access to this world is relentless to reason. ${ }^{14-19}$

Hence, philosophy should admit a complementary form of participation in the essence of things based on the emotional route. By establishing the base of his philosophy on emotional intuition, the theorist proposed new foundations, considering that the world of values gains validity independently of the subject, constituting a world in itself, whose values hide behind the feeling of value, as an objective and material fact, ranked by the subject. ${ }^{1}$

Thus, the senior students are able to rank the values that make them meaningful. The levels of this scale, when understood as a whole, reveal their cosmovision. Through this scale, they legitimize and justify their actions. It is through feeling that they list the values they consider appropriate for themselves. The moment of reason happens when they have to justify their choice for themselves and for the others. ${ }^{1}$

Therefore, the "logic of the heart" needs to be understood, as it is the center of affective life and houses the axiological field of nursing, in which the social value is considered. The deponents illustrated this assertion, saying that: [...] it means acting with tenderness [...] you are there to support the patient. It means being a subject capable of helping him to live and overcome his difficulty to live [...] you need to be humble, treat everyone in the same way, act naturally, give love to the nearest. It's not being mechanical. Do the procedure and leave. It means being at the side (E5). [...] imagine a situation in which you get dependent on another person. 'What would you want her to do for your? Take care of you? Feed you? Keep you company?' That is the idea of dependence (E8).

Hence, the senior student ratified Scheler's premise that, when the essence of nursing is rediscovered, based on its axiological field, its social value is identified. Thus, the students acknowledged the patients as singular, autonomous, spiritual beings who live with the others as peers. The patients and senior students are subjects responsible for themselves and co-accountable for the other, establishing solidarity as a to-be for the relationship in health praxis. ${ }^{14}$

\section{FINAL CONSIDERATIONS}

The social value could be identified and understood in the senior nursing students' discourse, manifested in the care pragmatics based on solidarity. Thus, the students acknowledged the social value as a belonging to the axiological field underlying the profession. It was there, in the pedagogical care practice, in their contact with the patient and relative that, through sympathy, they were able to consider the social value and judge it to be essential for nursing care.

The students cared about the patients, not only in their physical-biological dimension, but based on the acknowledgement of their humanity, that is, they perceived them as people and tried to establish a dialogical relationship with them. They valued nursing care based on Scheler's I-You relation and were able to understand that care is not only rooted in technical-scientific action. Although the logical-rational and empirical sciences constitute the knowledge field of the career, the "logic of the heart', as the center of affective life and values, it is its constitutive element, ratifying the art of nursing.

It was clear to them that their attitude was important to favor the wellbeing of the individuals under their care. Their action of "putting themselves aside" the patient and family member showed to be part of the actual essence of nursing. They started to acknowledge the patients not only as objects, but as people and, as such, having material and axiological gaps. Thus, they took distance from the perspective of the mass social clustering, counterattacked by Scheler, and started to value the individual as a person.

What nursing is concerned, solidarity is an intrinsic element of professional practice, as its 
characteristics derive not only from the knowledge of technical-scientific subjects, but from ethical, esthetic and personal knowledge. Thus, nursing, in a peculiar and creative manner, start to cover aspects of science and art, allowing nursing care to be conceived as the practice and knowledge of the profession, expressed in the praxis that rests on the acknowledgement of each patient's personality.

Despite the axiological crisis experienced in society, in which possession is sought as an end in itself, through the act of educating of the nurseteacher, the senior students move towards reflection and express their understanding about the axiological field of nursing, acknowled ging the social value as a founding value for the praxis of the profession, which can grow and develop in the Nurse-being, at the same time as they will be capable of transforming the praxis based on the new meaning attributed to nursing care.

Two elements are highlighted as study limitations. The first was the use of a convenience sample, as senior nursing students with similar positions can be selected. Nevertheless, it should be taken into account that the data collection was interrupted by the theoretical saturation, that is, when verifying the lack of new elements to understand the phenomenon. The second was the fact that the study was only undertaken at a single public higher education institution. Therefore, other studies are needed, considering opinions of students from other public and private institutions, which can unveil situations that had been not been noticed.

\section{REFERENCES}

1. Scheler M. Le formalisme en éthique et l'ethique matériale des valeurs. Paris (FR): Gallimard; 1955.

2. Werneck VR. Novos valores ou nova hierarquia de valores? Meta: Avaliação. 2010; 2(4):73-86.

3. Carvalho V. Ethics and values in health care practice: philosophical, educational, and political considerations. Rev Esc Enferm USP [Internet]. 2011 [cited 2014 Feb 10]; 45(Esp2):1793-8. Available from: http://www.scielo.br/pdf/reeusp/v45nspe2/en_28. pdf

4. Pires DEP. Transformações necessárias para o avanço da enfermagem como ciência do cuidar. Rev Bras Enferm [Internet]. 2013 [cited $2014 \mathrm{Feb}$ 10]; 66(esp):39-44. Available from: http://www. scielo.br/readcube/epdf.php?doi=10.1590/ S0034- $71672013000700005 \&$ pid $=S 0034$ $71672013000700005 \&$ pdf_path=reben/v66nspe / v66nspea05.pdf

5. Waldow VR, Fensterseifer LM. Saberes da enfermagem - a solidariedade como uma categoria essencial do cuidado. Esc Anna Nery Rev Enferm [Internet]. 2011 [cited 2014 Feb 20];15(3):629-32. Disponível em: http:/ / www.scielo.br/pdf/ean/v15n3/a27v15n3.pdf

6. Medeiros MB, Pereira ER, Silva RMCRA, Silva MA. Dilemas éticos em UTI: contribuições da Teoria dos Valores de Max Scheler. Rev Bras Enferm [Internet]. 2012 [cited 2014 Feb 20]; 65(2):276-84. Available from: http://www.scielo.br/pdf/reben/v65n2/v65n2a12. pdf

7. Guimarães GL, Viana LO. O valor social no ensino da enfermagem. Esc Anna Nery [Internet]. 2012 [cited 2014 Fev 20]; 16(3):508-13. Available from: http:// www.scielo.br/readcube/epdf.php?doi $=10.1590 /$ S1414-81452012000300012\& pid =S141481452012000300012\&pdf_path=ean/v16n3/12.pdf

8. Guimarães GL, Viana LO. O valor útil no ensino da enfermagem. REME Rev Min Enferm. 2011; 15(3):4216.

9. Paula CC, Padoin SMM, Terra MG, Souza IEO, Cabral IE. Modos de condução da entrevista em pesquisa fenomenológica: relato de experiência. Rev Bras Enferm [Internet]. 2014 [cited 2014 Sep 10]; 67(3):46872. Available from: http://www.scielo.br/pdf/ reben/v67n3/0034-7167-reben-67-03-0468.pdf

10. Almeida CSL, Sales CA, Marcon SS. The existence of nursing in caring for terminally ills'life: a phenomenological study. Rev Esc Enferm USP [Internet]. 2014 [cited 2014 Sep 12]; 48(1):34-40. Available from: http://www.scielo.br/pdf/reeusp/ v48n1/0080-6234-reeusp-48-01-34.pdf

11. Kisse EHS. O conceito de hermenêutica e sua aplicação no pensamento de W. Dilthey. Rev Litteris. 2012; 4(10):81-100.

12. Scheler M. Esencia y formas de la simpatía. Buenos Aires (AR): Editorial Losada; 2004.

13. Fernandes JD, Teixeira GAS, Silva MG, Florêncio RMS, Silva RMO, Rosa DOS. Expansion of higher education in Brazil: increase in the number of Undergraduate Nursing courses. Rev Latino-Am Enfermagem [Internet]. 2013 [cited 2014 Dec 16]; 21(3):670-8. Available from: http://www.scielo.br/pdf/rlae/ v21n3/0104-1169-rlae-21-03-0670.pdf

14. Scheler M. Da reviravolta dos valores. $2^{\mathrm{a}}$ ed. Petrópolis (RJ): Vozes; 2012.

15. Alves VH, Rodrigues DP, Gregório VRP, Branco MBLR, Souza RMP, Alves CMCSH. Reflexions about the value of breastfeeding as a health practice: a nursing contribution. Texto Contexto Enferm [Internet]. 2014 [cited 2015 Jan 10]; 23(1):203-10. Available from: http://www.scielo.br/pdf/tce/ v23n1/0104-0707-tce-23-01-00203.pdf

16. McCurry MK, Revell SM, Roy SC. Knowledge for the good of the individual and society: linking philosophy, disciplinary goals, theory, and practice. Nurs Philos [Internet]. 2010 [cited 2015 Oct 23]; 11(1):42-52. Available from: http://onlinelibrary.wiley.com/ doi/10.1111/j.1466-769X.2009.00423.x/pdf 
17. Willis DG, Grace PJ. Roy C. A central unifying focus for the discipline: facilitating humanization, meaning, choice, quality of life, and healing in living and dying. ANS Adv Nurs Sci. 2008; 31(1):E28-40.

18. Green C. Philosophic reflections on the meaning of touch in nurse patient interactions. Nurs Philos [Internet]. 2013 [cited 2015 Oct 23]; 14(1):242-53.
Available from: http://onlinelibrary.wiley.com/ doi/10.1111/nup.12006/pdf

19. Manara DF, Villa G, Moranda D. In search of salience: phenomenological analysis of moral distress. Nurs Philos [Internet]. 2014 [cited 2015 Oct 23]; 15(2): 171-82. Available from: http://onlinelibrary.wiley. com/doi/10.1111/nup.12048/pdf 